J. Environ. Sci.

Institute of Environmental Studies and Research - Ain Shams University

\title{
ASSESSMENT OF MICROBIAL AND CHEMICAL LOAD OF SOME DRINKING WATER PLANTS INTAKES IN GREATER CAIRO
}

\begin{abstract}
Abd-Eltawab, Mona, E. ${ }^{(1)}$; Kamel, A. H. ${ }^{(2)}$ and Arafa, Rawhia ${ }^{(3)}$
1) Basic Science Department, Institution of Environmental Studies and Research, Ain Shams University 2) Chemistry Department, Faculty of Science, Ain Shams University 3) Botany and Microbiology Department, Faculty of Science, Azhar University - Girl Branch
\end{abstract}

\begin{abstract}
Nile River is the main source of fresh water for domestic, agriculture, industry, fisheries and tourism purposes for most governorates in Egypt. Unfortunately, most of the drinking water plant intakes on Nile River. It is impacted by increasing concentrations of pollutants resulted from the agricultural drains located along its sides, industrial effluents and domestic waste from villages which have no sanitation system. This study aims at monitoring total coliform, Escherichia coli (E.coli), algae which may be related with the risk of diarrheal diseases and other diseases if they are present in water and suggesting limits for them in the criteria of drinking water plant intakes at Article 49 from decree No. 92 of 2013 in law No. 48 of 1982 for the protection of Nile River from pollution .

Samples from the drinking water plants intakes were collected in four seasons from September 2016 to October 2017. Each source of water samples was collected every month at three governorates : Cairo from (Al amarya - Al Tepeen - Manial Al Rawdah - Maadi ), Giza from (Embaba - El Saff - Gazirat Al Dahab -Giza - Al Hawamdiyah - Kafr Kandeel ), and Kalyobia from (Abo Zaabal - Al Reeyah El Tawfekey - El-Abadla - Basoos - Qualube ). The total numbers of samples were collected 210 to investigate: Total Coliform, Escherichia coli and algal count. Results showed that the Nile water at the studied locations contains high count of pathogenic indicator bacteria and algae where the mean of most probable number is $29859 / 100 \mathrm{ml}, 5923$ /100ml and 2656 unit / $1 \mathrm{ml}$ for total coliform, Escherichia coli and algal


count respectively. Diatoms is the prevalent algae type with percent $73.3 \%$ followed by green algae with percent $24 \%$ and the lowest is Cyanobacteria (blue green) with percent $2.7 \%$. Chemical oxygen demand (COD) was not complying with law No. 48 of 1982 in six intakes.

Keywords: Total coliform; Escherichia coli; drinking water plants intakes; Nile River; algal count; Diatoms; green algae; Cyanobacteria .

\section{INTRODUCTION}

Freshwater is essential for human life and its quality is a matter of global concern. Nile River is the life artery of Egypt and represents the main freshwater source needed for nearly all drinking and irrigation water demands (Ali, 2015). Surveillance of drinking water quality requires a systematic programme of surveys; it should cover the whole of the drinking-water system (WHO 2017).

The rise in the level of pollution due to drainage water from 67 agricultural drains 43 of which are considered major drains, industrial effluents and climate change are already challenges to water. The focus of this study is the intake of drinking water plants that may be related to the risk of diarrheal disease and other diseases in the case of presence of indicator pathogenic bacteria, contaminated water serves as a mechanism to transmit communicable diseases such as diarrhea, cholera, dysentery, typhoid and guinea worm infection. WHO estimates that in 2008 diarrheal disease claimed the lives of 2.5 million people for children under five; this burden is greater than the combined burden of HIV/AIDS and malaria (WHO 2011).

Excessive algal bloom in water resources can potentially limit their uses for recreation activities as well as for drinking water. However, their excessive growth or dense algal bloom in water resources diminishes the 
quality and quantity of light in the water column (U.S. EPA 2014). When blooms are excessive, the risk of toxin contamination released by harmful algal bloom (HABs) is likely to be elevated. The HAB includes many types of algal taxa such as diatoms, and cyanobacteria. Eutrophication caused by excessive algal bloom can cause fish kills and reduce the diversity of aquatic life (U.S. EPA 2014). In hypoxic water, dissolved oxygen levels can be less than $2-3$ ppm (U.S. EPA 2014). Three major phytoplankton groups were found to dominate the river Nile: green algae, blue-green algae, and diatoms (Salwa et al., 2016).

Article 49 from decree No. 92 of 2013 on freshwater limits does not contain bacterial or algal counts. Of course, this means that the microbial load is not investigated by water examining bodies. As water is treated in all drinking water plants in the same way without reference to the microbial content of the water entering the plants.

A conventional purification plants can be classified into two types: Central plants to supply a province or large city. It has a productivity of more than 17 thousand m3/day. Compact plants supply the villages and small communities and their productivity is limited according to population. In Egypt, Compact plants are use technologies like mobile units, direct filtration or slow sand filtration units (Mohammed, 2016).

The Nile River inside Egypt is completely controlled by the dams at Aswan in addition to a series of seven barrages between Aswan and the Mediterranean Sea. Accordingly, most of Drinking Water Treatment Plants DWTPs are constructed near the river. While, there are several canals that derived from river water such as Ismailia Canal. But these canals differ in 
water quality from the river itself due to industrial and agriculture activities as well as difference of their depth from the River Nile (Alaa, 2013).

The present study was aimed at evaluating the current water quality of Nile River in the governorates of Cairo, Giza and Qalyubia by collecting water samples monthly from the specified intakes in Greater Cairo. A Proposed bacterial and algal count for River Nile water can be suggested.

\section{MATERIALS AND METHODS}

Sample collection: Samples were collected in sterile glass bottle with ground-glass stopper. Sampling from the middle of the plants intakes by depth 1-2 meter from the surface. The bottle of microbial analysis should not be fully filled to allow the aerobic bacteria to grow.

Samples were collected from fifteen plants intakes of Cairo, Giza and Kalyobeya. Samples were collected in four seasons from september 2016 to october 2017 including less water flows period, determined by the Ministry of Water Resources and Irrigation (december until the first of march each year).

A total number of two hundred and ten samples, then examined for detection of chemical and microbial quality of water by investigating total coliform (TC), Escherichia coli (EC), total algal count, total dissolved solids (TDS), biological oxygen demand (BOD), chemical oxygen demand (COD), total Nitrogen (TN), total Phosphorus (Tp), lead, zinc, cadmium, chromium, organo phosphorus and chlorinated compound and are examined according to (APHA, 2005).

The total number was 210 samples and divided as follow, the first portion from Nile River was hundred and forty samples were examined during. The 
second portion from Ismailia Canal was forty two samples. The third portion from Al Reeyah El Tawfekey was twenty eight samples were examined during the four seasons. Total coliforms are the US Environmental Protection Agency (USEPA) standard indicators of pollution for waters (USEPA, 2002). Investigation of Total Coliform: By Multiple Tube Technique, analysis performed according to (APHA, 2005), buffer solution was prepared to dilute the concentration by dissolving potassium dihydrogen phosphate and magnesium sulphate then sterilized by autoclaving at $121 \mathrm{oC}$ for 15 minutes, lauryl tryptose broth media was prepared and sterilized by autoclaving at $1210 \mathrm{C}$ for 15 minutes, then Brilliant green broth prepared to confirm it. It was incubated at $35 \mathrm{oC}$ for 48 hours. The positive result was production of gas in the Durham tube so, a series of positive tubes containing brilliant green broth calculated from the most probable number (MPN) table.

\begin{tabular}{|c|c|c|c|}
\hline \multicolumn{2}{|c|}{ Lauryl Tryptose Broth } & \multicolumn{2}{c|}{ Brilliant green broth } \\
\hline Ingredients & Grams/Liter & Ingredients & Grams/Liter \\
\hline \hline Tryptose & $20 \mathrm{~g}$ & Pepton & $10 \mathrm{~g}$ \\
\hline Lactose & $5 \mathrm{~g}$ & Lactose & $10 \mathrm{~g}$ \\
\hline Sodium Chloride & $5 \mathrm{~g}$ & Ox-bile & $20 \mathrm{~g}$ \\
\hline $\begin{array}{c}\text { Mono potassium } \\
\text { Phosphate }\end{array}$ & $2.75 \mathrm{~g}$ & Sodium chloride & $5.0 \mathrm{~g}$ \\
\hline Disodium Phosphate & $2.75 \mathrm{~g}$ & Brilliant green & $0.0133 \mathrm{~g}$ \\
\hline $\begin{array}{c}\text { Sodium Lauryl } \\
\text { Sulfate }\end{array}$ & $0.1 \mathrm{~g}$ & Final PH $6.8 \pm 0.2$ at $25 \mathrm{oc}$ \\
\hline
\end{tabular}

Investigation of Escherichia coli: Analysis performed according to (APHA, 2005), prepared E.C broth media and distributed into tubes with Durham tubes, after that sterilized by autoclaving at $121 \mathrm{oC}$ for 15 minutes. 1 loopful was transferred from the positive total coliform and incubated at $44.5^{\circ} \mathrm{c}$ for 24 
hours. The positive result was production of gas in the Durham tube .Calculated from the most probable number (MPN) table.

Investigation and count of Algae: Algal count performed according to (APHA, 2005), the water samples have been concentrated by centrifugation, then discarded the supernatant and taken the precipitate with its dissolving water. Transferred $1 \mathrm{ml}$ on Sedgwick Rafter cell, and counted Diatoms, green algae and blue green algae.

\section{Determination of Biological Oxygen Demand (BOD):}

a. Preparation of dilution water: Transfer the water to a suitably sized bottle (glass is preferred). Check to ensure that the dissolved oxygen concentration is at least $7.5 \mathrm{mg} / \mathrm{L}$ before using water for BOD tests.

b. Sample temperature adjustment: Bring samples to $20 \pm 3^{\circ} \mathrm{C}$ before making dilutions.

Using the dilution water prepared, make at least three dilutions of prepared sample estimated to produce a residual DO of at least $1.0 \mathrm{mg} / \mathrm{L}$. Prepare dilutions in volumetric containers (Class A glass or equivalent) and then transfer to BOD bottles or prepare directly in BOD bottles.

The limits allowed in the regulated standards not more than $6 \mathrm{mg} / \mathrm{liter}$.

Determination of Chemical oxygen demand (COD): By open reflux method add all reagents to a sample larger than $50 \mathrm{~mL}$ and reduce total volume to $150 \mathrm{~mL}$ by boiling in the refluxing flask open to the atmosphere without the condenser attached. Compute amount of $\mathrm{HgSO} 4$ to be added (before concentration) on the basis of a weight ratio of 10:1, $\mathrm{HgSO} 4: \mathrm{Cl}-$, using the amount of $\mathrm{Cl}-$ present in the original volume of sample. Carry a blank reagent through the same procedure. 
The limits allowed in the regulated standards not more than $10 \mathrm{mg} / \mathrm{liter}$. Total nitrogen (TN): In water, nitrogen exists as inorganic and organic species. It was determined by indophenol method involving oxidation with sodium hypochlorite and phenol solution followed by spectrophotometric analysis at $640 \mathrm{~nm}$. The limits allowed in the regulated standards not more than $3.5 \mathrm{mg} / \mathrm{liter}$.

Total Phosphorus (Tp): In water, Phosphorus exists as inorganic orthophosphate, polyphosphate, and organic phosphate. Phosphorus (TP) is a measure of all forms of phosphorus found in water performed according to (APHA, 2005).

The limits allowed in the regulated standards not more than $2 \mathrm{mg} / \mathrm{liter}$.

Heavy Metals: Detected levels of lead, zinc, cadmium and chromium by atomic absorption performed according to (APHA, 2005). The limits allowed in the regulated standards for lead not more than $0.01 \mathrm{mg} / \mathrm{liter}$, for zinc not more than $0.01 \mathrm{mg} / \mathrm{liter}$, for cadmium not more than $0.001 \mathrm{mg} / \mathrm{liter}$ and chromium not more than $0.05 \mathrm{mg} / \mathrm{liter}$.

Organic compounds: Organics were extracted from water samples by liquid - liquid extraction technique using dichloromethane for aromatic hydrocarbons and $\mathrm{PAH}$, and 85:15 hexane / dichloromethane mixture for chlorinated hydrocarbons according to (APHA, 2005).

\section{RESULTS AND DISCUSSIONS}

The Nile River is the main source of fresh water for domestic, agriculture, industry, fisheries and recreation purposes for some governorates in Egypt. Egypt faces a rapidly increasing deterioration of its surface water 
due to increasing discharges of heavily polluted domestic, agriculture and industrial effluents into its waterways (Wahab, 2004). The amount of water that returns to drains from irrigated lands is relatively high about 25 to $30 \%$ (Allam, 2009).

These agricultural drains receive municipal wastewater from towns and villages located alongside them. Agricultural drains as usual been loaded by pesticides, and fertilizers and discharge into the Nile without treatment (Donia, 2005).

The River Nile is subjected to pollution in some areas from wastewater of industrial or agricultural origin. Canals branched from river Nile such as Ismailia Canal is considered more polluted because of the presence of many factories which drain their industrial wastewater into the canal in addition to pesticides drained from agriculture areas into the canal. The quality of its water is totally different from the River Nile water. It is much polluted due to presence of a lot of industrial factories such as paper, food, petroleum and petrochemical derivatives industries (Alaa,2013).

Table 1 displays the highest Total Coliform mean during the sampling period of the plants intakes was $67571 \mathrm{MPN} / 100 \mathrm{~cm} 3$ in Kafr Kandeel plant intake. On the other hand, the lowest Total Coliform mean during the sampling period of the plants intake was $10329 \mathrm{MPN} / 100 \mathrm{~cm} 3$ in Basoos plant intake.

The highest Escherichia coli mean during the sampling period of the plants intake was 13664 MPN/100cm3 in Kafr Kandeel plant intake. On the other hand, the lowest Total Coliform mean during the sampling period of the plants intake was 1907 MPN/100cm3 in Basoos. 
Total algal counts, recorded wide variation in sampling dates and that highest mean value was (3718 unit $/ \mathrm{mL}$ ) in Manial Al Rawdah plant intake. On the other hand, the lowest Algal count mean during the sampling period of the plants intake was $1783 \mathrm{MPN} / 100 \mathrm{~cm} 3$ in Benha plant intake.

Diatoms considered the predominant species of algal counts in river Nile water since, percent of diatoms ranged between 71-75\%. Diatoms attained their maximum mean value in the intake of Manial Al Rawdah, where recorded (2737 unit $/ \mathrm{mL}$ ).On the other hand, diatoms attained their minimum mean value in Benha intake where recorded (1305 unit $/ \mathrm{mL})$.

Green algae considered the second predominant species of algal counts in river Nile water since, percent of Green algal count ranged between $21-26$ $\%$. Green algae attained their maximum mean value in Gezira Al Dahab intake where recorded ( 884 unit $/ \mathrm{mL}$ ). On the other hand, minimum mean value of green algal count of the total algal population was recorded in Benha intake (427 unit/mL).

Blue green algae considered the least predominant species of algal counts in Nile water since, percent of blue green algal count ranged between $2-3.6$ $\%$. Blue green algae attained their maximum mean value in the intake Manial Al Rawdah which counted (109 unit/mL). On the other hand, blue green algae attained their minimum mean value in the intake of Abu Zaabl (45 unit /mL). In presence of bloom or eutrophication microcystine must be determined according to the ministerial decree number 458/2007.

There was an increase in the mean of total coliform in this study compared to the results of Alaa (2013) where the mean was in the intake of Al Tepeen plant $11200 \mathrm{MPN} / 100 \mathrm{~cm} 3$ while in this study was 18164 
MPN/100cm3. While similar results were obtained in the algae where diatom was the most common in the Nile water followed by green algae and finally blue green algae.

Table (1): Average values of Total Coliform, Escherichia coli and Alga in the studied drinking water plants intakes in greater Cairo

\begin{tabular}{|c|c|c|c|c|c|c|}
\hline \multirow{2}{*}{$\begin{array}{l}\text { Water plant } \\
\text { intake }\end{array}$} & \multicolumn{2}{|c|}{ MPN/100 $\mathrm{cm}^{3}$} & \multicolumn{4}{|c|}{ Unit /ml Algae } \\
\hline & $\begin{array}{c}\text { Total } \\
\text { Coliform } \\
\end{array}$ & $\begin{array}{c}\text { Escherichia } \\
\text { coli }\end{array}$ & $\begin{array}{l}\text { Total } \\
\text { Count } \\
\end{array}$ & $\begin{array}{c}\text { Diatom } \\
\mathbf{S} \\
\end{array}$ & Green & $\begin{array}{l}\text { Blue } \\
\text { Gree }\end{array}$ \\
\hline Qualube & 16936 & 6414 & 2312 & 1710 & 540 & 62 \\
\hline Maadi & 11871 & 1929 & 3118 & 2295 & 738 & 82 \\
\hline Abu Zaabal & 43000 & 10021 & 2233 & 1637 & 551 & 45 \\
\hline Abadla & 18021 & 2000 & 2375 & 1761 & 562 & 52 \\
\hline $\begin{array}{c}\text { Al Reeyah } \\
\text { (Benha) }\end{array}$ & 15679 & 2750 & 1783 & 1305 & 427 & 51 \\
\hline Giza & 22221 & 3842 & 3042 & 2158 & 797 & 88 \\
\hline Embaba & 30021 & 4164 & 2000 & 1499 & 428 & 73 \\
\hline Al Tepeen & 18164 & 4293 & 2898 & 2134 & 679 & 86 \\
\hline Al Dahab & 36471 & 8186 & 3549 & 2562 & 884 & 103 \\
\hline Hawamdiyah & 42257 & 5085 & 3019 & 2192 & 714 & 92 \\
\hline El amarya & 36857 & 8943 & 2097 & 1545 & 482 & 49 \\
\hline Kafr Kandeel & 67571 & 13664 & 3013 & 2219 & 723 & 70 \\
\hline El Saff & 48593 & 12050 & 2765 & 1971 & 731 & 64 \\
\hline Basoos & 10329 & 1907 & 2899 & 2138 & 679 & 83 \\
\hline Rawdah & 29893 & 3600 & 3718 & 2737 & 865 & 109 \\
\hline Mean & 29859 & 5923 & 2721 & 1991 & 563 & 74 \\
\hline
\end{tabular}

Table 2 showed that no considerable change was observed for $\mathrm{pH}$, total dissolved salts, biological oxygen demand (BOD), total phosphorus (T.P), total nitrogen (T.N) and ammonia (NH3) during the study where all results still in acceptable limit at decree 92/2013. 
The mean of chemical oxygen demand (COD) was not applicable with decision 92/2013, in Amarya, Kafr Kandeel, Basoos, Qualube, Abu Zaabal, Al Reeyah plants intakes.

Table (2): Average values of the studied parameters in the studied drinking water plants intakes in greater Cairo

\begin{tabular}{|c|c|c|c|c|c|c|c|}
\hline Intake & PH & TDS & BOD & COD & T.P & T.N & NH3 \\
\hline Maadi & 8 & 269 & 3.7 & 9.7 & nil & 0.36 & 0.15 \\
\hline Rawdah & 7.9 & 270 & 3.5 & 9.6 & Nil & 0.32 & 0.13 \\
\hline El Saff & 7.9 & 259 & 4.3 & 9.8 & 0.044 & 0.33 & 0.158 \\
\hline Tepeen & 7.8 & 265 & 3.95 & 9.7 & 0.03 & 0.35 & 0.15 \\
\hline Amarya & 7.8 & 265 & 4.9 & 11.14 & Nil & 0.32 & 0.14 \\
\hline Embaba & 7.8 & 287 & 3.5 & 9.6 & Nil & 0.359 & 0.165 \\
\hline Al Dahab & 7.8 & 279 & 3.7 & 9.75 & 0.03 & 0.32 & 0.15 \\
\hline Hawamdiyah & 7.8 & 277 & 3.9 & 9.7 & Nil & 0.3 & 0.16 \\
\hline Kandeel & 7.7 & 259 & 4.3 & 10.47 & 0.019 & 0.36 & 0.13 \\
\hline Giza & 7.7 & 296 & 4 & 9.8 & Nil & 0.3 & 0.15 \\
\hline Abadla & 7.7 & 251 & 1.4 & 9.47 & Nil & 0.2333 & 0.1 \\
\hline Basoos & 7.7 & 281 & 2 & 11.86 & Nil & 0.25 & 0.14 \\
\hline Qualube & 7.6 & 270 & 2.2 & 14 & Nil & 0.331 & 0.1 \\
\hline Abu Zaabal & 7.5 & 298 & 2.5 & 12.7 & Nil & 0.4 & 0.078 \\
\hline $\begin{array}{c}\text { Al } \\
\text { Reeyah(Benha) }\end{array}$ & 7.5 & 287 & 2.03 & 14.35 & Nil & 0.48 & 0.16 \\
\hline Mean & 7.7 & 274.5 & 3.297 & 10.95 & 0.031 & 0.33 & 0.137 \\
\hline
\end{tabular}

Table 3 showed that the mean of heavy metals which examined during the sampling period of the plants intake was applicable with decree 92/2013.

Alaa(2013) results showed that lead, zinc, chromium and cadmium were not detectable (less than the detection limit of the atomic absorption used) in all sample locations and sample dates, that mean Compatible with this study. 
Table (3): Average values of some heavy metals in some drinking water plants intakes in greater Cairo

\begin{tabular}{|c|c|c|c|c|}
\hline Intake & Cr & Cd & Pb & Zn \\
\hline \hline El Maadi & 0.0026 & 0.0002 & 0.0014 & 0.0002 \\
\hline Rawdah & 0.004 & 0.0002 & 0.0015 & 0.0002 \\
\hline El Saff & 0.0027 & 0.0003 & 0.0014 & 0.0007 \\
\hline Tepeen & 0.0028 & 0.0002 & 0.0013 & 0.0001 \\
\hline Amarya & 0.0029 & 0.0003 & 0.002 & 0.0085 \\
\hline Embaba & 0.003 & 0.0003 & 0.0014 & 0.0078 \\
\hline Al Dahab & 0.0028 & 0.0002 & 0.0067 & 0.0008 \\
\hline Hawamdiyah & 0.003 & 0.0003 & 0.0014 & 0.0007 \\
\hline Kandeel & 0.003 & 0.0003 & 0.007 & 0.00 \\
\hline Giza & 0.0014 & 0.0003 & 0.0012 & 0.0014 \\
\hline Abadla & 0.005 & 0.0003 & 0.015 & 0.011 \\
\hline Basoos & 0.002 & 0.0015 & 0.0201 & 0.0217 \\
\hline Qualube & n.d & 0.0016 & 0.0218 & 0.0786 \\
\hline Abu Zaabal & 0.0027 & 0.0002 & 0.0114 & 0.0222 \\
\hline Al Reeyah & 0.003 & 0.0002 & 0.017 & 0.0108 \\
\hline Mean & 0.002946 & 0.00044 & 0.0078 & 0.0118 \\
\hline
\end{tabular}

CONCLUSION

1- In conclusion, this study reported that River Nile at some points is suffering from enormous pollution sources such as domestic waste and agriculture waste which violate the environmental laws for protection of Nile.

2- Survey for River Nile water comply with standards except COD which is not within the acceptable limits in Amarya, Kafr Kandeel, Basoos, Qualube, Abu Zaabal, Al Reeyah plants intakes.

3- The present investigation revealed that the indicators for pathogen bacteria in river Nile water indicated that total coliform has a mean of 10329 
$67571 \mathrm{MPN} / 100 \mathrm{~cm} 3$ during the sampling period of the plants intakes while Escherichia coli has a mean of 1907 - 13664 MPN/100cm3, also total algal count mean during the sampling period of the plants intakes between 1783 - 3718 unit/1ml.

\section{REFERENCES}

Alaa, M. F., (2013): "Application of Mobile Water Maker in Surface water treatment". Thesis, M.Sc., Environmental Researches and Studies Institute, Ain Shams University.

Allam, F. M., (2009): "Drainage water treatment by constructed wetlands". Thesis, M.Sc., Environmental Researches and Studies Institute, Ain Shams University.

Ali M., (2015): Indices of water quality and metal pollution of Nile River. J. Aquatic. Res. 9 (22), 1492-1498.

American Public Health Association, (APHA) (2005): Standard Methods for Examination of Water and Wastewater.

Donia, N., (2005): Rosetta Branch Waste Load Allocation Model. 19th International Water Technology Conference, Sharm El-Sheikh, Egypt, pp: 277-288: Conference, Alex., Egypt, pp: 901-912.

Mohammed, A.,(2016): Ammonia removal from surface water in water purification plants on Rosetta branch. Thesis, M.Sc., Environmental Researches and Studies Institute, Ain Shams University.

Shehata, A. S. and Bader A. (2016): Effect of Nile River water quality on algal distribution at Cairo. https://doi.org/10.1016/01604120(85)90230-2Get rights and content.

U.S. Environmental Protection Agency, (USEPA, 2002): "Trace elements in water, solids and bio solids by inductively coupled plasmaatomic emission spectrometry : method 200.7", Revision 5.0 
U.S. Environmental Protection Agency, (USEPA 2014): Harmful Algal Blooms \& Drinking Water Treatment.

Badawy, M. I., (2004): Water Quality Assessment of the River Nile System: An Overview, Biomedical and Environmental sciences 17 (2004) 87-100.

World Health Organization (WHO 2011): Cause-specific mortality: regional estimates for 2008. Geneva, World Health Organization.

World Health Organization (WHO 2017): GUIDELINES FOR DRINKINGWATER QUALITY: fourth edicorporating the first addendum. P:9.

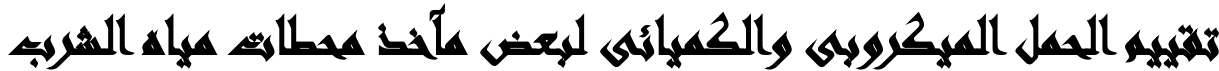

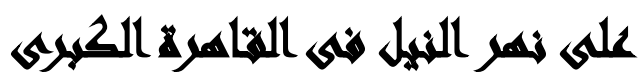

\section{$[r]$}

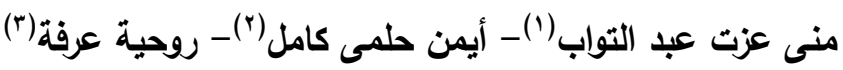

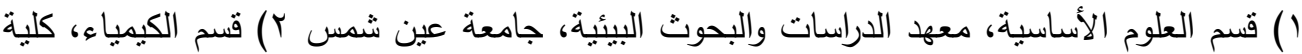

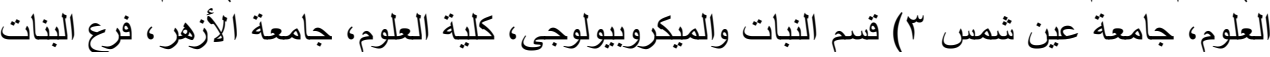

\section{ll}

يعتبر نهر النيل المصدر الرئيسي للمياه العذبة التى تستحدم فى الأغراض المنزلية والزراعة

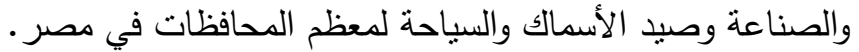

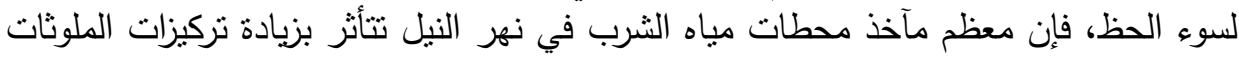

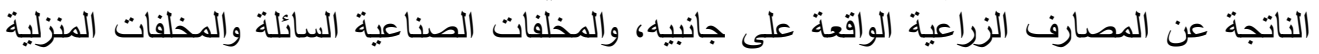
من القرى التي لا يوجد بها نظام صرف صحي. تهدف هذه الدراسة إلى الى مراقبة وراتية ورصد بكتريا

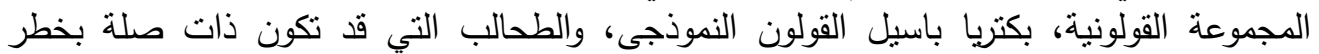

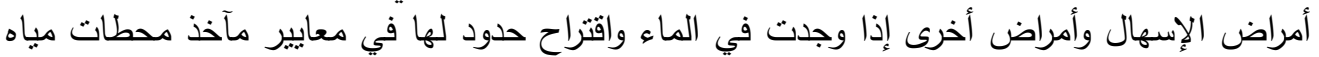

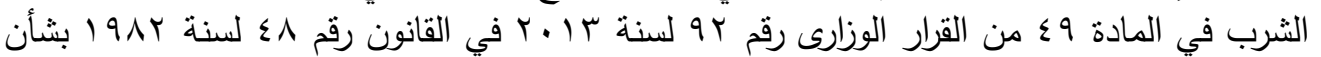

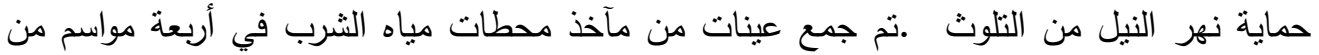

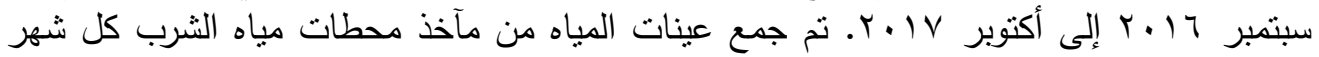

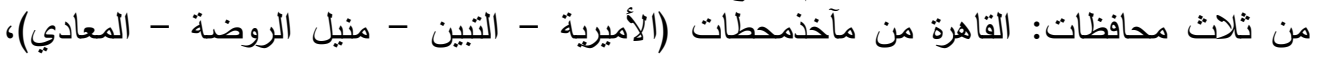
الجيزة من مآخذ محطات (امبابه - الصف - جزئ منيرة الدهب - الجيزة - الحوامدية - كفر قنديل)،

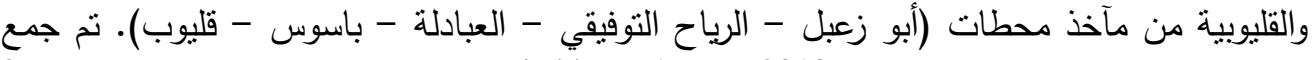
26 
J. Environ. Sci.

Institute of Environmental Studies and Research - Ain Shams University

عدد · اب عينة لفحص: المجموعة القولونية و باسيل القولون النموذجى وعدد الطحالب. أوضحت

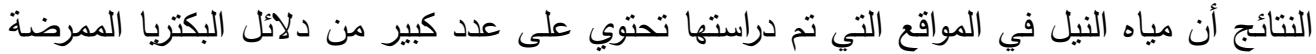

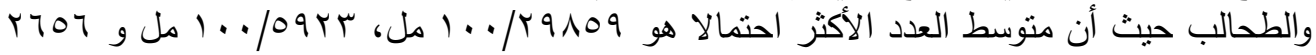

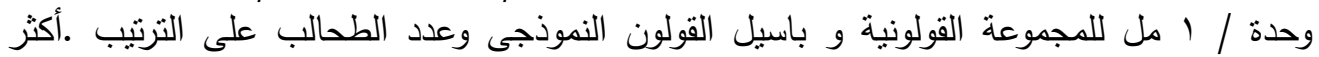

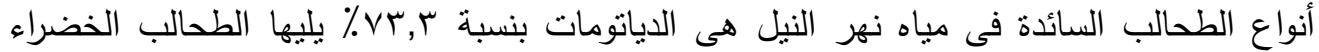

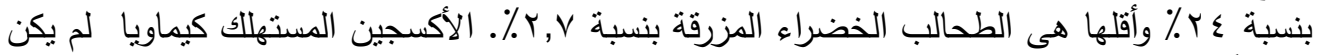

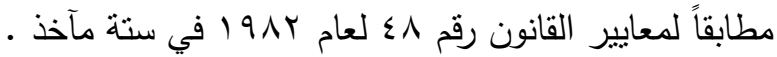

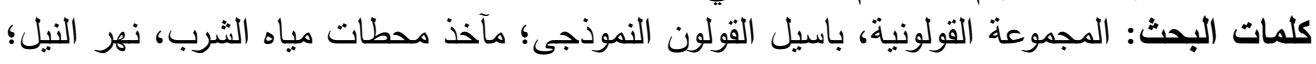

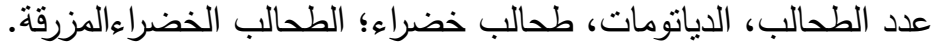

